\title{
A protein with amino acid sequence homology to bovine insulin is present in the legume Vigna unguiculata (cowpea)
}

\section{T.M. Venâncio, \\ A.E.A. Oliveira, \\ L.B. Silva, O.L.T. Machado, \\ K.V.S. Fernandes and \\ J. Xavier-Filho}

\author{
Laboratório de Química e Função de Proteínas e Peptídeos, \\ Centro de Biociências e Biotecnologia, \\ Universidade Estadual do Norte Fluminense, \\ Campos dos Goytacazes, RJ, Brasil
}

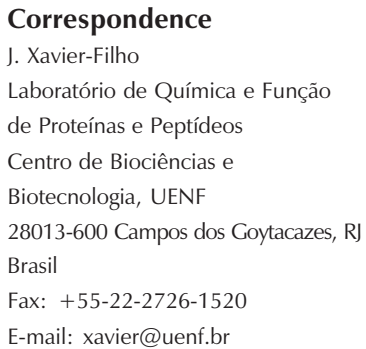

Research supported by CAPES, CNPq, PRONEX, FINEP, and Universidade Estadual do Norte Fluminense (FENORTE).

Received October 14, 2002

Accepted May 21, 2003

...................

\begin{abstract}
Since the discovery of bovine insulin in plants, much effort has been devoted to the characterization of these proteins and elucidation of their functions. We report here the isolation of a protein with similar molecular mass and same amino acid sequence to bovine insulin from developing fruits of cowpea (Vigna unguiculata) genotype Epace 10. Insulin was measured by ELISA using an anti-human insulin antibody and was detected both in empty pods and seed coats but not in the embryo. The highest concentrations (about $0.5 \mathrm{ng} / \mu \mathrm{g}$ of protein) of the protein were detected in seed coats at 16 and 18 days after pollination, and the values were 1.6 to 4.0 times higher than those found for isolated pods tested on any day. N-terminal amino acid sequencing of insulin was performed on the protein purified by $\mathrm{C}_{4}$-HPLC. The significance of the presence of insulin in these plant tissues is not fully understood but we speculate that it may be involved in the transport of carbohydrate to the fruit.
\end{abstract}

Key words

- Insulin

- Insulin-like

- Cowpea

- Vigna unguiculata

- Developing fruits

- Sequence homology

- Evolution

\section{Introduction}

The peptide hormone insulin was discovered in 1921 in connection with the treatment of diabetes mellitus and was isolated from the pancreas of dogs (1). Later, it was shown by others to be a small protein of about $6 \mathrm{kDa}(2)$. Insulin was one of the first proteins to be crystallized (3) and was the first to be sequenced in 1955 (4). Right after the discovery of insulin, members of the Canadian group involved in the work reported the presence of similar hypoglycemic activity in plant materials such as the green tops of onions, lettuce and bean leaves, bar- ley and beet roots, and others $(5,6)$. Collip (5) coined the word glucokinin to refer to the plant-isolated material because he did not accept that a protein of plant origin should be named insulin (from the Latin insula) since plants do not possess the pancreatic islets (of Langerhans) from which insulin was isolated.

Although many reports on the beneficial effects of plant-derived materials on the alleviation of diabetes symptoms continued to appear (7), it was only in 1974 that further work on the possible presence of insulin in plants appeared. Khanna et al. (8-10) reported on the isolation of a protein from the 
fruits of the bitter gourd (Momordica charantia) that exerted positive effects on diabetic patients and showed properties similar to those of insulin. Following these reports, Collier et al. (11) reported on the isolation from spinach, rye and Lemna gibba of proteins with molecular masses, chromatographic properties, immunological identity and biological activities identical to those of vertebrate insulins. No structural information was given for these molecules at the time.

Recently, in our laboratory we discovered by chance that a protein isolated from the seed coats of the legume Canavalia ensiformis (jack bean) has the same molecular mass and amino acid sequence as that of bovine insulin. We further showed that the purified protein reacts with anti-vertebrate insulin antibodies and lowers blood glucose levels in diabetic animals. We also found associated with this protein a 15 -amino acid sequence fragment, which showed a high sequence homology with a receptor protein kinase from humans (12). We have also shown that insulin-like antigens are present in the leaves of several green plants, fungi and a cyanobacterium, suggesting a wider distribution of this protein than is commonly thought (13).

It is well known that insulin is part of signaling pathways involved in the internalization of glucose in several types of vertebrate cells $(14,15)$. Insulin also has effects on protein synthesis and gene transcription (16). In addition, insulin has been detected in tissues of members of several other phyla, suggesting that these pathways have been evolutionarily conserved (17-19). In plants, apart from many reports on the lowering of blood sugar levels in diabetic animals by extracts of plant parts $(20,21)$, no place for insulin as a member of signaling pathways has been suggested by workers interested in the study of glucose mobilization or transport (22-24). Nevertheless, it has been shown that addition of bovine insulin increases germination of some seeds (25-27), accelerates synthesis of ribosomal proteins in germinating maize embryos $(28,29)$, and increases the activity of glyoxysomal enzymes which catalyze the conversion of fat to carbohydrate in some fat-storing seeds (25).

In the present paper we report on the isolation and characterization of insulin from the fruit of cowpea (Vigna unguiculata) as well as changes in its concentration during fruit development.

\section{Material and Methods}

\section{Plant material}

Cowpea (Vigna unguiculata (L.) Walp.) seeds of the Epace 10 genotype were obtained from the Departamento de Fitotecnia, Universidade Federal do Ceará, Fortaleza, $\mathrm{CE}$, Brazil. Seeds were sown in pots containing locally collected soil at the Centro de Ciências e Tecnologias Agropecuárias, Universidade Estadual do Norte Fluminense, Campos dos Goytacazes, RJ. After 10 days, seedlings were transferred to soil in a greenhouse. Flowers were tagged at opening and fruits were collected at 4, 6, 8, 10, 12, 14, 16, 18 and 20 days after pollination (DAP). At 10 DAP, fruits were divided into empty pods and seeds (cotyledons plus seed coats); from 12 to 20 DAP fruits were divided into empty pods, cotyledons and seed coats. All parts were weighed before and after freeze-drying. After drying, materials were finely powdered and kept at $-20^{\circ} \mathrm{C}$ for analysis.

\section{Insulin extraction}

The divided powders were extracted by the method of Khanna et al. (9) for the extraction of polypeptide-p, which is what these workers named their insulin preparations from bitter gourd (M. charantia) fruits. Five grams of tissue was extracted with a solution consisting of $2 \mathrm{ml}$ distilled water, 10 $\mathrm{ml} 95 \%$ ethanol and $0.72 \mathrm{ml}$ concentrated sulfuric acid. After shaking for $20 \mathrm{~min}, 13 \mathrm{ml}$ 
water and $40 \mathrm{ml} 95 \%$ ethanol were added and the preparation was again shaken for another 20 min when the $\mathrm{pH}$ was adjusted to 1.7 with sulfuric acid. The suspension was then filtered and the filtrate taken to $\mathrm{pH} 3.0$ with ammonium hydroxide. To this new suspension $150 \mathrm{ml}$ of $95 \%$ ethanol and $200 \mathrm{ml}$ of diethyl ether were added. After standing for $12 \mathrm{~h}$ at $4^{\circ} \mathrm{C}$ the suspension was centrifuged at 3,000 $\mathrm{g}$ for $10 \mathrm{~min}$ and the sediment was washed with acetone and diethyl ether before dissolving in $25 \%$ ethanol, $\mathrm{pH}$ 8.5. To this solution $100 \mu \mathrm{l}$ of $1 \mathrm{M}$ zinc chloride was added and the preparation was left to stand for $18 \mathrm{~h}$ at $25^{\circ} \mathrm{C}$ to precipitate insulin and other insulin-immunoreactive proteins. The precipitate was collected by centrifugation.

\section{Antibodies}

A highly purified antibody (Cat. No. GGG7303/971577) against human insulin raised in guinea pigs was purchased from Peninsula Laboratories, San Carlos, CA, USA. A peroxidase-conjugated guinea pig anti-IgG antibody (A5545) raised in goats was from Sigma, St. Louis, MO, USA.

\section{Protein determination}

Total protein in the extracts was measured by the method of Bradford (30) using ovalbumin as standard.

\section{ELISA}

Insulin was measured by ELISA using a guinea pig anti-human insulin antibody (Peninsula Laboratories) applied to separated parts of the $V$. unguiculata fruit (see above) according to the following procedure. The samples were freeze-dried and extracted with $0.1 \mathrm{M}$ carbonate/bicarbonate buffer, $\mathrm{pH} 9.6$ $(15 \mathrm{mg} / \mathrm{ml})$. After centrifugation for clarification, the extracts were diluted with carbonate/bicarbonate containing $50 \mathrm{mM}$ EDTA at $4^{\circ} \mathrm{C}$. The wells of a 96-well Maxisorp type plate (Nunc, Roskilde, Denmark) were treated overnight with $100 \mu \mathrm{l}$ of a solution containing $15 \mu \mathrm{g}$ of total protein from each sample diluted in carbonate/bicarbonate buffer, $\mathrm{pH}$ 9.6. We then treated the wells with a solution of $2 \%$ gelatin in sodium phosphatebuffered saline (PBS) containing 0.05\% Tween 20. Next we treated the wells with 50 $\mu \mathrm{l}$ anti-insulin $\operatorname{IgG}(1: 5000)$ for $1 \mathrm{~h}$ at $37^{\circ} \mathrm{C}$. The wells were then submitted to frequent washes with PBS $0.05 \%$ Tween 20 solution. As a second antibody we employed an antiIgG + peroxidase (1:3000). A standard curve for bovine insulin was always run alongside the samples. Negative controls were performed employing the IgG-peroxidase complex without addition of the anti-insulin IgG and a blank well with no added antibody. The reaction was developed with ortho-phenylenediamine and stopped with $3 \mathrm{~N} \mathrm{H}_{2} \mathrm{SO}_{4}$. The plates were read at $492 \mathrm{~nm}$ in a spectrophotometer.

\section{Polyacrylamide gel electrophoresis and Western blotting}

Samples (50 mg) were extracted overnight in buffer ( $0.1 \mathrm{M}$ Tris, $10 \%$ sucrose, $0.1 \%$ SDS, and $0.005 \%$ bromophenol blue) and after clarification they were heated to $100^{\circ} \mathrm{C}$ for $5 \mathrm{~min}$. SDS-PAGE was done under nonreducing conditions. After $15 \%$ acrylamide gel electrophoresis (31), protein bands were visualized by Coomassie brilliant blue and silver staining. Western blotting (32) was done on nitrocellulose membranes utilizing a semi-dry device for electrotransfer of proteins and a buffer made up of $25 \mathrm{mM}$ Tris, $192 \mathrm{mM}$ glycine and $20 \%$ methanol. Transfer was performed at 1 $\mathrm{mA} / \mathrm{cm}^{2}$ for $4 \mathrm{~h}$. After transfer and blocking with nonfat milk, proteins were identified using a guinea pig anti-insulin (human) antibody (1:3000) as primary antibody and an IgG-peroxidase complex (1:2000). A positive reaction was visualized by chemiluminescence using an Amersham Biosciences (São Paulo, SP, Brazil) detection kit. 


\section{Reverse-phase HPLC}

Proteins were separated and purified by RP-HPLC using a 50 × $5 \mathrm{~mm} \mathrm{C4}$ Vydac column with a $0-80 \%$ acetonitrile in $0.1 \%$ TFA gradient. The fraction obtained by zinc chloride precipitation ( $50 \mu \mathrm{g}$ of protein) was

\begin{tabular}{lc}
$\begin{array}{l}\text { Table 1. Total insulin in fruits of cowpea (Vigna } \\
\text { unguiculata) as a function of time after pollination. }\end{array}$ \\
\hline $\begin{array}{l}\text { Days after } \\
\text { pollination }\end{array}$ & $\begin{array}{c}\text { Insulin } \\
\text { ( } \mu \text { insulin per fruit) }\end{array}$ \\
\hline 4 & $0.456 \pm 0.039$ \\
6 & $1.90 \pm 0.09$ \\
8 & $3.27 \pm 0.11$ \\
10 & $4.635 \pm 0.221$ \\
12 & $7.1 \pm 0.173$ \\
14 & $9.67 \pm 0.306^{*}$ \\
16 & $12 \pm 1.428^{*}$ \\
18 & $10.84 \pm 0.691^{*}$ \\
20 & $1.28 \pm 0.026$
\end{tabular}

Data are reported as mean \pm SD for 7 whole fruits. Insulin was measured by ELISA with antihuman insulin antibodies. The asterisks indicate that these three measurements do not differ statistically $(P<0.05$, Student $t$-test $)$.

Table 2. Insulin levels per protein and dry weight of plant part in fruits of cowpea (Vigna unguiculata) as a function of time after pollination.

\begin{tabular}{lcc}
\hline Days after pollination & \multicolumn{2}{c}{ Insulin } \\
\cline { 2 - 3 } & (ng insulin/ $\mu$ g protein) & (ng insulin/mg dry weight) \\
& $0.48 \pm 0.04$ & $7.27 \pm 0.656$ \\
4 (whole fruit) & $0.47 \pm 0.015$ & $8.95 \pm 0.278$ \\
6 (whole fruit) & $0.46 \pm 0.017$ & $10.05 \pm 0.346$ \\
8 (whole fruit) & $0.47 \pm 0.023$ & $11.4 \pm 0.548$ \\
10 (empty pod) & $0.46 \pm 0.012$ & $7.8 \pm 0.173$ \\
12 (empty pod) & $0.48 \pm 0.015$ & $8.65 \pm 0.28$ \\
14 (empty pod) & $0.44 \pm 0.07$ & $5.1 \pm 0.751^{* * *}$ \\
16 (empty pod) & $0.51 \pm 0.053$ & $18.15 \pm 1.89^{*}$ \\
16 (seed coat) & $0.35 \pm 0.015^{*}$ & $4.1 \pm 0.18^{* * *}$ \\
18 (empty pod) & $0.56 \pm 0.04$ & $20.2 \pm 1.5^{* *}$ \\
18 (seed coat) & $0.36 \pm 0.01^{*}$ & $5.4 \pm 0.15^{* *}$ \\
20 (seed coat) &
\end{tabular}

Insulin was measured by ELISA using an anti-human insulin antibody. In samples 4, 6 and 8 days after pollination (DAP), insulin was measured in the whole fruit. In sample 10 DAP, fruits were divided into seeds (plus seed coats) and empty pods. In samples 12 DAP to 20 DAP, fruits were divided into seed coats, cotyledons and empty pods. Seeds (cotyledons plus axes) of 10, 12, 14, 16, 18 and 20 DAP fruits did not contain any insulin as measured by ELISA. The same number of asterisks indicates that the data do not differ statistically $(P<0.05$, Student $t$-test; $N=7$ ). dissolved in $500 \mu \mathrm{l}$ of $0.1 \%$ TFA containing $0.1 \mathrm{M}$ EDTA and applied to the column. The column was operated at $0.7 \mathrm{ml} / \mathrm{min}$ and proteins were detected by absorbance at 280 $\mathrm{nm}$. Bovine insulin (ca. $300 \mu \mathrm{g}$ of protein in $500 \mu \mathrm{l})$ was used as a standard to compare retention times.

\section{$\mathrm{N}$-terminal sequencing}

N-terminal amino acid sequencing was performed on a Shimadzu PPSQ-10 Automated Protein Sequencer (Kyoto, Japan) by Edman degradation (33). Sequences were determined for the RP-HPLC peak (C4 column) with the same retention time to that of bovine insulin. About $200 \mathrm{pmol}$ of $V$. unguiculata insulin was submitted to $\mathrm{N}$-terminal sequencing. Proteins were not reduced/alkylated in order to prevent loss of cysteine residues, and thus we observed two phenylthiohydantoin $(\mathrm{PTH})$-amino acids per cycle. PTH-amino acids were detected at $269 \mathrm{~nm}$ after separation on a reverse-phase C18 column (4.6 $\mathrm{mm} \times 2.5 \mathrm{~mm})$ under isocratic conditions according to the manufacturer instructions (Shimadzu PPSQ-10 Protein Sequencer). The sequences obtained were compared to sequences reported in amino acid data banks and submitted to automatic alignment, which was performed using the NCBI-BLAST search system (34).

\section{Results}

\section{Presence of insulin antigen in developing cowpea fruits}

An immunoreactive insulin, as demonstrated by ELISA utilizing an anti-human insulin antibody, was shown to be present in developing whole fruits of cowpea from 4 to 20 DAP. The levels of insulin per fruit increased up to 16 DAP and then fell at 20 DAP when fruits were dry (Table 1). When the results were plotted as ng insulin per $\mu \mathrm{g}$ protein (Table 2) no difference in the insulin 
concentrations was observed in fruits up to 16 DAP. At 18 DAP, insulin concentration decreased in empty pods and increased in seed coats. At 20 DAP the antigen was demonstrable in seed coats but not in empty pods. This could be due to the inability to solubilize insulin from the dried pods by the buffer utilized (Table 2). No insulin was detected in seeds from 10 to 14 DAP fruits or in the cotyledons of any developmental stages of the cowpea fruit (data not shown). When we plotted specific activity of insulin (ng) per tissue dry weight (mg) (Table 2) we observed that the values found for seed coats from 16 and 18 DAP fruits were 1.6 to 4.0 times higher than the values found for isolated pods at the same stages (Table 2).

\section{Identification of the immunoreactive insulin}

When the extracts (10 DAP empty pods) containing the insulin antigen were submitted to SDS-PAGE we detected a protein band in the same position as a bovine insulin band with a molecular mass of approximately $6 \mathrm{kDa}$ (Figure 1A). The insulin standard has more than one band probably because of the property of insulin to form aggregations. When a similar gel was treated with the antiinsulin antibody employed by us, the band at the same position as insulin (ca. $6 \mathrm{kDa}$ ) stained positive, indicating the presence of insulin-like antigens in the plant materials (Figure 1B). The same insulin-positive bands were seen in gels originating from extracts obtained from materials of different DAP (data not shown). These results indicate that the insulin antigen present in cowpea fruits has the same molecular weight as vertebrate insulins.

The insulin-like protein isolated as described in Methods (9) was also submitted to RP-HPLC, using commercial bovine insulin as standard. The insulin-like material isolated from cowpea fruits and commercial bovine insulin presented similar chromatographic behavior (Figure 2).
The definitive proof of the identity of the molecule came when we submitted it to $\mathrm{N}$ terminal amino acid sequencing. The protein present in the major peak (absorbance at 280 nm, 31-min retention time) obtained by RPHPLC (Figure 2) was used for automatic Edman sequencing. The resulting sequence was shown to be identical to the sequence of bovine insulin (Figure 3). Since the insulin had not been reduced and alkylated by sequencing, the molecule had intact disulfides and thus no PTH-cysteine was obtained. Note that all the $\mathrm{X}$ 's in Figure 3 correspond to cysteine in native insulin. Thus, we can conclude that the sequence of the $V$. unguiculata protein is identical to bovine insulin.

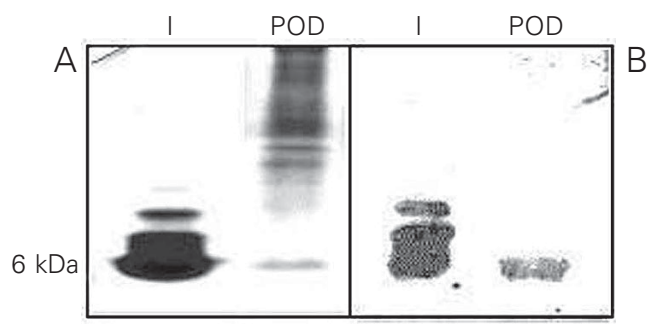

Figure 1. SDS-PAGE and Western blot of proteins extracted from 10 days after pollination (DAP) pods (empty) of cowpea (Vigna unguiculata). SDS-PAGE was done under nonreducing conditions. A, Protein staining with Coomassie brilliant blue (50 ul). B, Western blot. I, bovine insulin; POD, proteins isolated from empty pods of 10 DAP fruits.

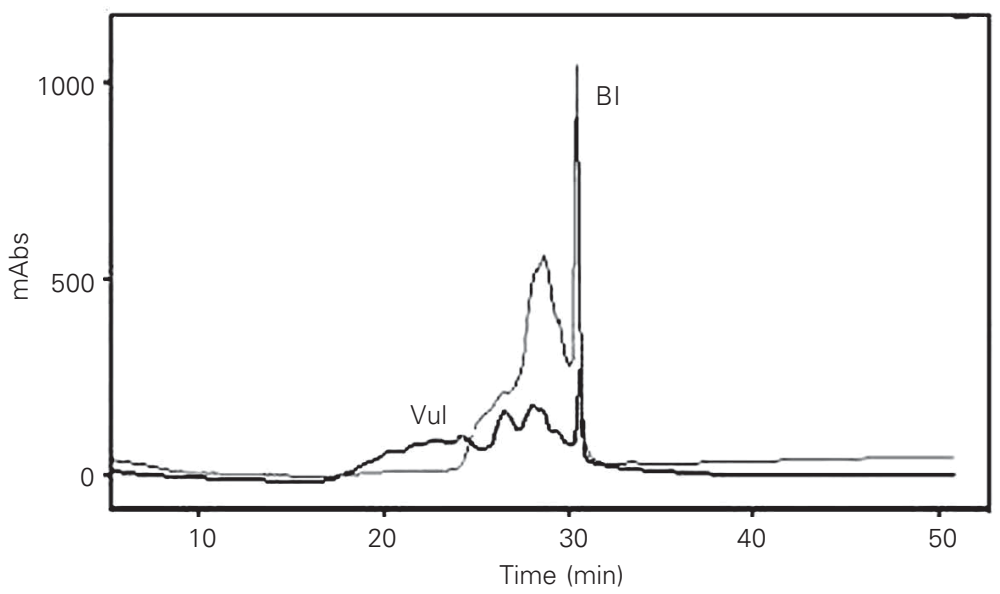

Figure 2. Reverse-phase HPLC separation of bovine insulin (BI, $300 \mu \mathrm{g})$ and of insulin isolated from empty pods of 10 days after pollination fruits of Vigna unguiculata (Vul, 50 $\mu \mathrm{g}$ ). The column was operated at $0.7 \mathrm{ml} / \mathrm{min}$ and proteins were detected by absorbance at $280 \mathrm{~nm}$ and a gradient of acetonitrile and $0.1 \%$ TFA was applied to the column as described in Methods. The light line indicates the elution profile of insulin and the dark line, the profile of the cowpea extract. 


\section{GIVEQCCASVCSLYQLENYCN \\ $\alpha$ chain of bovine insulin \\ GIVEQXXASVXSLYQLENYXN protein isolated from $V$. unguiculata}

FVNQHLCGSHLVEALYL VCGER GFFYTPKA $B$ chain of bovine insulin FVNQHLXGSHLVEALYLVXGER GFFYTPKA protein isolated from $V$. unguiculata

Figure 3. Alignment of the sequence found by automatic amino acid sequencing of the fraction isolated by RP-HPLC of cowpea (Vigna unguiculata) insulin with the sequence of bovine insulin (gi229095). Sequences were compared using the NCBI-BLAST search system. Cysteine residues were not detected since proteins were not reduced/alkylated; an $\mathrm{X}$ appearing in the sequence indicates that the amino acid at that position is probably a cysteine residue.

\section{Discussion}

It is well known that during fruit development in legumes such as cowpea and others, photosynthate enters the embryo (sink) through the pod and the seed coat (35). It is also thought that sucrose is mostly hydrolyzed to glucose and fructose by invertase in order to enter the cotyledons (35). The isolation of a protein from the developing fruits of cowpea ( $V$. unguiculata) with positive immunoreactivity to anti-human insulin antibody and amino acid sequence identity with bovine insulin would suggest that insulin might be involved in the transport of sugars (e.g., glucose) to the embryo, a role similar to the one exerted by this hormone in vertebrates (14) and invertebrates alike (36). Strong data suggest that insulin enhances the metabolism of germinating maize seeds (27) and also of some fat-storing seeds (25). Recently, our group demonstrated that insulin stimulates the germination of Canavalia ensiformis (Oliveira AEA, Ribeiro ES, Da Cunha M, Gomes VM, Fernandes KVS and Xavier-Filho J, unpublished results) and Phaseolus vulgaris seeds (Santos VO, Silva LB, Oliveira AEA, Da Cunha M, Fernandes KVS and Xavier-Filho J, unpublished results).

Further identification of the insulin antigen with bovine insulin was obtained by RPHPLC of the insulin-like protein isolated by the method of Khanna et al. (9). Comparison of its retention time with that for bovine insulin showed an identical chromatographic profile, suggesting once again that the molecule we isolated was the same as bovine insulin (Figure 2).

The levels of insulin-like protein in fruits first increased and then decreased with the development of the fruits (Table 1). The phase of decreased concentration of insulin corresponds to the ripening phase, when fruits lose water and the seeds become dry and metabolically less active (37). The presence of insulin in higher amounts when the fruit is metabolically active is an indication of a possible role for insulin in fruit. Insulin in plants may be involved in signaling events, as suggested by us and by others $(12,13,38)$.

It is interesting to note that the sequence of the protein found in developing cowpea fruits and reported here is identical to the sequence of the insulin we have isolated from seed coat tissues of the jack bean, another legume plant (12). The presence of insulin-like antigens in plant tissues was reported previously by Collier et al. (11) and more recently by us (13).

The findings reported in the present study of yet another plant which contains insulin strengthen the view that the peptide hormone insulin is evolutionarily conserved throughout living organisms, including microbes (18), insects (36) and plants (11,12, $27)$, probably participating in similar signaling pathways.

\section{References}

1. Banting FG \& Best $\mathrm{CH}$ (1922). The internal secretion of the pancreas. Journal of Laboratory and Clinical Medicine, 7: 465-480.

2. Harfenist EJ \& Craig LC (1952). The molecular weight of insulin. Journal of the American Chemical Society, 74: 3087-3089.

3. Abel JJ (1926). Crystalline insulin. Proceedings of the National
Academy of Sciences, USA, 12: 132-136.

4. Sanger $F$ (1959). Chemistry of insulin. Science, 129: 1340-1344

5. Collip JB (1923). Glucokinin. A new hormone present in plant tissue. Preliminary paper. Journal of Biological Chemistry, 56: 513-543.

6. Best CH (1924). Recent work on insulin. Endocrinology, 8: 617-629 
7. Gray AM \& Flatt PR (1997). Nature's own pharmacy: The diabetes perspective. Proceedings of the Nutrition Society, 56: 507-517.

8. Khanna P, Nag TN, Jain SC \& Mohan S (1974). Extraction of insulin from a plant source. 3rd International Congress on Plant Tissue and Cell Cultures, July 21-26, Leicester, UK.

9. Khanna P, Nag TN, Chandrajaia S \& Mohan SV (1976). Process for isolation of insulin from plant source. United States Patent. Patent number 3,945,988.

10. Khanna P, Jain SC, Panagariya A \& Dixit VP (1981). Hypoglycemic activity of polypeptide-P from a plant source. Journal of Natural Products, 44: 648-655.

11. Collier E, Watkinson A, Cleland CF \& Roth J (1987). Partial purification and characterization of an insulin-like material from spinach and Lemna gibba G3. Journal of Biological Chemistry, 262: 6238-6247.

12. Oliveira AEA, Machado OLT, Gomes VM, Xavier-Neto J, Pereira AC, Vieira JGH, Fernandes KVS \& Xavier-Filho J (1999). Jack bean seed coat contains a protein with complete sequence homology to bovine insulin. Protein and Peptide Letters, 6: 15-21.

13. Silva LB, Santos SSS, Azevedo CR et al. (2002). The leaves of green plants as well as a cyanobacterium, red alga, and fungi contain insulin-like antigens. Brazilian Journal of Medical and Biological Research, 35: 297-303.

14. Baumann CA, Ribon V, Kanzaki M, Thurmond DC, Mora S, Shigematsu S, Bickel PE, Pessin JE \& Saltiel AR (2000). CAP defines a second signalling pathway required for insulin-stimulated glucose transport. Nature, 407: 202-207.

15. Brüning JC, Gautmam D, Burks DJ, Gillette J, Schubert M, Orban PC, Klein R, Krone W, Müller-Wieland D \& Kahn CR (2000). Role of brain insulin receptor in control of body weight and reproduction. Science, 289: 2122-2125.

16. Alper J (2000). New insights into type 2 diabetes. Science, 289: 3739.

17. LeRoith D, Delahunty G, Wilson GL, Roberts Jr CT, Shemer J, Hart C, Lesniak MA, Shiloach J \& Roth J (1986). Evolutionary aspects of the endocrine and nervous systems. Recent Progress in Hormone Research, 42: 549-587.

18. LeRoith D, Shiloach J, Heffron R, Rubinovitz C, Tanenbaum R \& Roth J (1985). Insulin-related material in microbes: similarities and differences from mammalian insulins. Canadian Journal of Biochemistry and Cell Biology, 63: 839-849.

19. Chan SJ \& Steiner DJ (2000). Insulin through the ages: phylogeny of a growth promoting and metabolic regulatory hormone. American Zoology, 40: 213-222.

20. Ernst E (1997). Plants with hypoglycemic activity in humans. Phytomedicine, 4: 73-78.

21. Platel K \& Srinivasan K (1997). Plant foods in the management of diabetes mellitus: vegetables as potential hypoglycaemic agents. Nahrung, 41: 68-74.
22. Ward JM, Kühn C, Tegeder M \& Frommer WB (1998). Sucrose transport in higher plants. International Review of Cytology, 178: 41-71.

23. Lemoine $R$ (2000). Sucrose transporters in plants: update on function and structure. Biochimica et Biophysica Acta, 1465: 246-262.

24. Williams LE, Lemoine R \& Sauer N (2000). Sugar transporters in higher plants - a diversity of roles and complex regulation. Trends in Plant Sciences, 5: 283-290.

25. Goodman DBP \& Davis WL (1992). Insulin accelerates the post germinative development of several fat storing seeds. Biochemical and Biophysical Research Communications, 190: 440-446.

26. Wobus U \& Weber H (1999). Sugars as signal molecules in plant seed development. Biological Chemistry, 380: 937-944.

27. Oliveira AEA, Azevedo CR, Venâncio TM et al. (2001). Insulin in plants. Plant Biology-2001, Providence, RI, USA, July 21-25, 1999, 29 (Abstract).

28. Sánchez de Jiménez E, Beltrán-Penã E \& Ortíz-López A (1999). Insulin-stimulated ribosomal protein synthesis in maize embryonic axis during germination. Physiologia Plantarum, 105: 148-154.

29. Dinkova TD, Aguilar R \& Sánchez de Jiménez E (2000). Expression of maize eukaryotic initiation factor (elF) iso4E is regulated at the translational level. Biochemical Journal, 351: 825-831.

30. Bradford MM (1976). A rapid and sensitive method for the quantitation of microgram quantities of protein utilizing the principle of protein-dye binding. Analytical Biochemistry, 72: 248-254.

31. Laemmli KA (1970). Cleavage of structural protein during assembly of the head of bacteriophage T4. Nature, 227: 680-685.

32. Towbin H, Staehelin NT \& Gordon J (1979). Electrophoretic transfer of proteins from polyacrylamide gels to nitrocellulose sheets; procedures and some applications. Proceedings of the National Academy of Sciences, USA, 176: 4350-4354.

33. Edman $P$ (1950). Method for determination of amino acid sequence in peptides. Acta Chemica Scandinavica, 4: 283-293.

34. Altschul SF, Gish W, Miller W, Myers EW \& Lipman DJ (1990). Basic local alignment search tool. Journal of Molecular Biology, 215: 403-410.

35. Offler CE \& Patrick JW (1993). Pathway of photosynthate transfer in the developing seed of Vicia faba $L$ - A structural assessment of the role of transfer cells in unloading from the seed coat. Journal of Experimental Botany, 44: 711-724.

36. Sower SA, Suzuki K \& Reed KL (2000). Perspective: Research activity of enteropancreatic and brain/central nervous system hormones across invertebrates and vertebrates. American Zoology, 40: $165-178$.

37. Bewley JD \& Black M (1994). Seeds: Physiology of Development and Germination. 2nd edn. Plenum Press, New York.

38. Ryan CA, Pearce G, Scheer J \& Moura DS (2002). Polypeptide hormones. Plant Cell, 14: 251-264. 